\title{
Pengelolaan Villa Sanyas Dalam Mengatasi Ketidaknyamanan Wisatawan Terhadap Aktivitas Wisata Malam Di Kawasan Seminyak Bali
}

Pinkqi Gracesyani Tibuludjia, 1, Ida Bagus Suryawan a, 2 11pinkhycia@gmail.com, 2idabagussuryawan@unud.ac.id

a Program Studi S1 Destinasi Pariwisata, Fakultas Pariwisata,Universitas Udayana, Jl. Dr. R. Goris, Denpasar, Bali 80232 Indonesia

\begin{abstract}
The research is located in Villa Sanyas area of Seminyak-Kuta Bali. The research was conducted to find out how the management villa sanyas, and also to know the factors that make the tourist stay at villa sanyas feel uncomfortable. the choice of Seminyak as the location of this research according to th place where the tourism grows fastly. On the development stage, that tourism area still need various research from some point of view. Thus, this research focuses to identify factors which affects the uncomfortness during stay in Villa Sanyas Seminyak. This research is very important and could be reference as solutions for comfortness of tourists in Villa Sanyas.

The method of data collecting in this research are observation, interview, and documentation to analyze the data collected with descriptive qualitative analysis while primary data and secondary data. The determining of informants use is purposive sampling.

Results of the study found that most tourist who stay at villa sanyas feel disturbed by the noise can be heard up to the villa, besides that also some employees who work in villa sanyas not fluent in english. Based on the report, can be suggested to the villa management to improve the quality of service toward the tourists who stay, then the tourist will feel comfort.
\end{abstract}

Keywords : comfortness, tourists, management and night tourism.

\section{PENDAHULUAN}

Bali adalah daerah tujuan wisata yang ramai dikunjungi turis asing maupun turis mancanegara, serta mempunyai alam yang indah dan budaya unik yang tidak dimiliki kota lain. Bali juga merupakan salah satu penyumbang devisa negara terbesar melalui pariwisatanya. Turis yang mengunjungi Bali bukan hanya mencari keindahan alam, tetapi juga ingin menikmati budaya unik dan tradisi masyarakat lokal serta ingin bersenangsenang.

Di Bali terutama di daerah Seminyak banyak terdapat tempat-tempat hiburan malam berupa cafe, bar/diskotik. Hiburan malam ini menjadi daya tarik yang menyenangkan bagi para turis yang sedang berlibur di Bali. Dibangunnya sarana-sarana dan prasarana yang cukup lengkap, menjadi tempat favorit turis untuk berlibur. Tetapi disamping itu juga, kenyamanan wisatawan menjadi situasi yang penting dalam berwisata. Faktor tersebut pada dua puluh tahun terakhir telah menjadi kabar yang semakin besar dan memiliki efek terhadap berlangsungnya aktivitas wisata. Semakin berkembangnya pariwisata di Indonesia khsusnya di Bali merupakan suatu tantangan yang cukup kompleks dalam memberikan kenyamanan dan keamanan (comfort and safety) bagi turis (Zimanyi, 2011).

Faktor kenyamanan di suatu tempat wisata adalah suatu poin tambahan dan kesempatan untuk dikunjungi turis asing maupun turis mancanegara. Faktanya, terkadang suatu tempat tujuan wisata, banyak wisatawan yang merasa tidak nyaman yang disebabkan oleh sikap dan perilaku tuan rumah atau host. Permasalahan ini sering terjadi di tempat wisata. Faktor kenyamanan disuatu tempat wisata merupakan nilai tambah dan peluang untuk di kunjungi oleh turis seperti yang dimaksud bahwa tujuan wisata di negara berkembang sudah saatnya memberikan jaminan keselamatan dan rasa aman bagi turis selama melakukan aktivitas wisata UNWTO (2004).

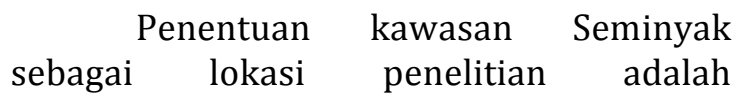


perkembangan pariwisata yang begitu padat dan ramai dikunjungi oleh wisatawan. Pada tahap pengembangan, lokasi wisata tersebut masih membutuhkan berbagai penelitian yang diambil dari berbagai sudut pandang. Salah satunya tentang kenyamanan wisatawan yang menginap di villa atau hotel sekitar daerah wisata Seminyak Bali. Wisatawan yang menginap di Villa Sanyas sering mengeluh karena terdengarnya suara bising dari tempat wisata malam sekitar Villa Sanyas.

Dengan demikian, penelitian tentang Pengelolaan Villa Sanyas dalam mengatasi Aktivitas Wisata Malam terhadap Ketidanyamanan Wisatawan di Villa Sanyas Seminyak Bali dipandang penting karena villa sanyas menjadi salah satu villa favorit yang menjadi tempat menginap wisatawan karena berada di pusat daerah Seminyak dan hasil penelitian ini diharapkan dapat menjadi solusi untuk mendapat penyelesaian masalah dari faktor kenyamanan turis yang menginap di villa Sanyas.

\section{TINJAUAN PUSTAKA}

Penelitian ini menggunakan beberapa pedoman konsep untuk menganalisis data yang didapat di lapangan, yaitu:

1. Konsep Pengelolaan adalah sekelompok orang yang mencapai hasil akhir organisasi secara bersama. Selain itu pengelolaan memungkinkan kerjasama antar individu atau orangorang di dalam organisasi untuk mencapai suatu tujuan yang diinginkan (Hasibuan, 2004: 41).

2. Konsep Kenyamanan dalam sudut pandang kesehatan merupakan keadaan yang sudah tercapai kebutuhan dasar turis. Kebutuhan tersebut meliputi ketentraman, kelegaan dan transenden (Setiawan, 2012),

Dalam hal ini peneliti menggunakan dua aspek antara lain :

a. Lingkungan, berkaitan dengan latarbelakang pengalaman diluar turis seperti bunyi cahaya, warna, temperatur dan berbagai unsur alamiah lain.

b. Sosial, berkaitan dengan interpersonal, keluarga maupun sosial.

3. Konsep Wisatawan merupakan seseorang yang berkunjung ke suatu tempat atau negara dan menetap selama 24 jam yang bertujuan untuk bersenangsenang, berlibur, belajar, keperluan agama dan olahraga, bisnis, keluarga, pertemuan dan utusan (UNWTO, 1994).

4. Konsep Hiburan Malam sejenis tempat tourist attraction atau kegiatan dimana para turis juga dapat merupakan subyek yang pasif atau aktif sebagai pengunjung yang datang untuk menikmati dan menyaksikan pertunjukan atau kejadian yang berlangsung guna mendapatkan kesenangan rohaniah sesuai dengan keinginan para turis yang dilakukan pada waktu malam hari (Darmajati, 2001).

\section{METODE}

Lokasi penelitian ini dilakukan di kawasan Seminyak, jln.Cendrawasih no.9 Petitenget, Seminyak-Kuta, Kota Denpasar provinsi Bali. Adapun ruang lingkup penelitian untuk dapat memperjelas permasalahan yang akan diteliti adalah :

1. Faktor yang mengganggu kenyamanan wisatawan yaitu : Lingkungan dan Sosial.

2. Upaya yang dilakukan pengelola pihak Villa dalam menangani ketidaknyamanan wisatawan terhadap aktivitas wisata malam meliputi: Segmen pasar dan kerja sama antar karyawan.

Dalam penelitian ini menggunakan jenis data kualitatif seperti hasil wawancara yang ditulis dengan deskriptif, gambaran umum lokasi penelitian, dan sumber data dalam penelitian ini data primer dan data sekunder (Sugiyono 2014).

Dalam mengumpulkan data digunakan tiga cara, yaitu: Observasi, wawancara semi terstruktur dan dokumentasi (Sugiyono 2014). 
Teknik analisis data pada penelitian ini menggunakan kualitatif deskriptif yaitu dilakukan dengan langkah perpanjangan pengamatan, dan meningkatkan ketekunan (Sugiyono, $2014: 270$ ).

\section{IV.HASIL DAN PEMBAHASAN}

Villa Sanyas berada di kawasan Seminyak, jln.Cendrawasih no.9 Petitenget, Seminyak-Kuta. Lokasinya sangat strategis karena berada di jantung Petitenget dan menjadi daya tarik tersendiri untuk wisatawan menginap disana karena dekat dengan Pantai Seminyak dan Pantai Kayu Putih. Semua karyawan yang bekerja di Villa ini sudah sesuai dengan job description, karena receptionist yang siap melayani wisatawan selama 24 jam, dan juga pekerja lain yang ramah dalam melayani wisatawan sudah cukup membuat wisatawan yang menginap merasa puas dan senang. Meskipun Villa ini berlokasi sangat strategis dan berada di tengah-tengah kota, harga permalam Villa ini cukup terjangkau, fasilitas dan pelayanan di Villa tersebut cukup memuaskan untuk wisatawan lokal maupun mancanegara yang menginap.

Villa Sanyas merupakan sebuah Villa kompleks yang dirancang dengan filosofi sanyasin, yaitu tempat yang tepat untuk mencapai kebahagiaan, bahkan Villa Sanyas dirancang untuk relaksasi dan beristirahat dari rutinitas sehari-hari karena sangat dekat dengan berbagai tempat hiburan. Villa Sanyas mempunyai 15 tipe villa pribadi diantaranya :

- 6 unit Deluxe suite villa dengan tipe 1 kamar tidur yang dilengkapi kolam renang pribadi

- 7 unit Junior suite villa dengan tipe 1 kamar tidur yang dilengkapi dengan kolam renang pribadi

- 1 unit Royal suite villa dengan tipe 2 kamar tidur yang dilengkapi dengan kolam renang pribadi

- 1 unit Executive suite villa dengan tipe 2 kamar tidur yang besar dan lengkap dengan kolam renang pribadi

Masing-masing Villa memiliki satu dan dua kamar tidur yang dilengkapi dengan berbagai fasilitas penunjang yang tentunya membuat wisatawan yang menginap merasa nyaman. Namun disamping itu, terdapat beberapa faktor yang mempengaruhi kenyamanan wisatawan yang menginap.

Faktor yang mengganggu kenyamanan dan keamanan wisatawan adalah sebagai berikut :

a. Lingkungan

Lingkungan di dominasi oleh beberapa tempat hiburan malam diantaranya Discotheque, Night Club, Pub dan Bar and Cafe. Yang menyebabkan kebisingan di sekitar villa dan hal ini mengganggu kenyamanan wisatawan.

\section{b. Sosial}

Sebagian karyawan yang bekerja di villa tidak begitu lancar berbahasa inggris, sehingga terkadang wisatawan menjadi susah dalam berkomunikasi, ataupun jika membutuhkan sesuatu.

Langkah-langkah yang dilakukan pihak pengelola Villa Sanyas:

a. Segmen Pasar

Untuk sementara langkah yang selanjutnya diambil oleh pihak pengelola Villa adalah menjual harga kamar tipe executive suite villa lebih murah dibandingkan tipe Villa yang lain untuk wisatawan yang menginap. Sambil menunggu langkah selanjutnya dari pemilik Villa yaitu merenovasi ulang kamar di lantai dua executive suite villa agar tidak terdengar lagi kebisingan dari tempat hiburan malam sekitar villa Sanyas.

Dalam hal merenovasi mereka lebih memfokuskan untuk merenovasi tipe executive suite villa yaitu dengan memasang alat peredam suara ataupun getaran, agar kedepannya wisatawan yang menginap merasa nyaman dan tidak complain lagi terhadap pihak pengelola villa Sanyas. Pihak pengelola Villa sudah merencanakan jika sebelum High Season (bulan Juli-Agustus) kamar Villa tersebut sudah harus selesai di renovasi agar wisatawan yang menginap 
di Villa Sanyas Seminyak merasa nyaman dan citra Villa tersebut tidak negatif di mata wisatawan.

b. Sosial

Pihak pengelola sudah berupaya agar karyawan bisa memberikan pelayanan yang memuaskan bagi wisatawan yang berkunjung, agar wisatawan merasa nyaman dan mau menginap kembali di Villa Sanyas.

Sejauh ini pihak pengelola sudah memberikan training atau pelatihan bagi karyawan yang belum fasih berbahasa inggris, agar wisatawan yang berkunjung merasa lebih nyaman dan tidak kesulitasn saat berkomunikasi.

\section{SIMPULAN DAN SARAN}

\section{A. Simpulan}

Simpulan yang didapat dari penelitian ini adalah :

1. Wisatawan yang menginap di Villa Sanyas merasa tidak nyaman karena suara bising yang terdengar dari tempat wisata malam sekitar villa Sanyas. Dan hal ini tidak bisa dibiarkan, sebab akan mengganggu waktu liburan wisatawan yang ingin bersantai dan juga menikmati liburan mereka dengan nyaman tanpa ada gangguan. Karena bukan hanya satu wisatawan saja yang complain tetapi sudah sering wisatawan yang menginap di Sejauh ini upaya yang dilakukan pihak pengelola villa sanyas adalah menjual kamar dengan harga yang murah, tetapi tetap melakukan suatu upaya untuk merenovasi kamar tersebut agar wisatawan yang menginap tidak merasa terganggu.

2. Kerjasama antar karyawan

Pihak pengelola sudah mulai merencanakan untuk menciptakan suatu hubungan yang baik antar karyawan untuk mencapai target yang telah direncanakan oleh pihak pengelola. Disamping itu pihak sudah melatih karyawan yang belum fasih berbahasa inggris, agar bisa berbahasa inggris dengan lancar agar wisatawan yang menginap tidak merasa kesulitan saat membutuhkan sesuatu.

B. Saran

Saran yang didapat dalam penelitian ini adalah :

1. Meningkatkan fasilitas kenyamanan disekitar Villa seperti menambah peredam getaran dan suara disekitar dinding kamar, juga terus meningkatkan fasilitas yang sudah ada.

2. Manajemen pihak villa sebaiknya lebih meningkatkan kinerja kerja karyawan dan dilatih supaya fasih berbahasa inggris agar wisatawan yang menginap merasa betah dan ingin kembali menginap disana.

\section{DAFTAR PUSTAKA}

Anonim. Republik Indonesia. 2009. Undang-undang No. 10 Tahun 2009 Tentang Kepariwisataan. Jakarta: Sekretariat Negara

Cooper. 1996: 16. Konsep Wisatawan

Kolcaba 1992. dalam Potter \& Perry, 2005. Konsep kenyamanan wisatawan.107

Pitana, Gayatri. 2005; 53. Pariwisata ada karena adanya wisatawan

Sugiyono. 2014. Metode Penelitian Kualitatif dan Kombinasi (Mixed Methods). Bandung: Alfabeta 